\title{
Vesicoileocutan sztóma, a gyógyíthatatlan húgycsőszükületek egy lehetséges megoldása
}

\author{
Oroszi Márton dr., Rosecker Ágnes dr., Pajor László dr., \\ Papos István dr., Bajory Zoltán dr. \\ Szegedi Tudományegyetem, Urológiai Klinika, Szeged (igazgató: Bajory Zoltán dr.)
}

\author{
Levelezési cím: \\ Dr. Oroszi Márton \\ SZTEÁOK, Urológiai Klinika \\ 6725 Szeged, Kálvária sgt. 57. \\ E-mail: \\ oroszi.marton.ferenc@med.u- \\ szeged.hu
}

\begin{abstract}
ÖSSZEFOGLALÁS
Célkitűzés: A szerzők gyógyíthatatlan kombinált urethraszúkület egy lehetséges operatív megoldását mutatják be.

Beteg és módszer: 2006 és 2015 között 4 esetben készítettünk vesicoileocutan sztómát. A hólyagnyak körül kialakuló hegszövet okai az endourológiai beavatkozások, kismedencei trauma, irradiáció és a radikális prostatectomia voltak.

A mútét során 10-15 cm-es ileumszakasz lett izolálva, ezzel létrehoztuk az összeköttetést a hólyag és a bőrfelszín között, amelyen át ürül a vizelet. A hólyag és az uréterszájadékok megőrzésével nem jöhet létre az uréterointesztinális anasztomózis szúkülete, ami a Bricker-hólyag képzés gyakori szövődménye.

Eredmények: A betegek elégedettek voltak a vizeletes sztómájukkal, könnyen megtanulták a kezelését és így megszabadultak a totál retenciótól való félelmüktől. Korai szövődmény nem fordult elő, a késői szövődményeket - perinealis fisztula, sztómaszükület, parasztómális hernia - sikeresen megoldottuk.
\end{abstract}

Következtetések: Átjárhatatlan urethraszükületes betegeknél, ultimum refugiumként alkalmazható a vesicoileocutan sztóma képzés.

\section{KULCSSZAVAK}

HÚGYCSŐSZÜKÜLET, EPICYSTOSTOMIA, VIZELETRETENCIÓ, HÓLYAG-AUGMENTÁCIÓ

\section{Bevezetés}

Az egyre gyakrabban kialakuló súlyos szúkület és teljes húgycsőelzáródás leggyakoribb oka: az egyre jobban elterjedó endourológiai mútétek és katéterhasználat (1). A további okok lehetnek a radikális prostatectomia, szövődményes antiinkontinens mútétek, neurogén hólyag egyes esetei, valamint balesetek, kismedencei traumák következményei. Ezen betegek egy részénél a teljes vizeletelakadás mellett, illetve annak kezelése miatt inkontinencia is kialakulhat. Az inkontinencia vég-

\section{The vesicoileocutaneostomy: a definitive} solution for incurable urethral stricture

\section{SUMMARY}

Objective: The authors present a successful operative solution for incurable combined urethral stricture.

Patients and method: Between 2005 and 2015 vesicoileocutaneo-stomy was performed in four patients. Urethral stricture, irradiation, radical prostatectomy and small pelvic trauma were the basic cause of developing the dense scarification around the bladder neck. A 10-15 cm long ileum was isolated for the connection of the bladder and the skin surface. The patient passes the urine through a stoma. The preservation of the bladder and the ureteral orifices avoid the patient from the stricture formation at the level of the ureterointestinal anastomosis as it is a usual complication in the Bricker-bladder.

Results: The patients are satisfied with the urine stoma as they get rid of the danger of total retention. Early complication was not obsessed, the late complications - perineal fistula, stoma stricture and parastomal hernia - were successfully repaired.

Conclusion: As "ultimum refugium" vesicoileocutaneostomy can be performed in patient with dense urethral stricture.

\section{KEYWORDS}

URETHRAL STRICTURE, EPICYSTOSTOMY, TOLTAL URINARY RETENTION, BLADDER AUGMENTATION

leges mútéti megoldása kontraindikált húgycsőszúkület esetén. A betegek különben is a vizeletelakadást élik meg roszszabbul - ez egy állandó fenyegetettség - ezért elöször annak gyógyítására törekszünk. Megoldás a gyakorlatban: tágító mútétek, urethrotomiák, vagy definitív epicystostoma behelyezése, esetleg ultimum refugiumként Bricker-hólyag képzés. Felmerül a kérdés, hogy miért kell használaton kívül helyezni egy különben jól múködő hólyagot? A vázolt nehézségeket és leginkább a beteg kényelmét vesicoileocutan sztómával oldottuk meg. 


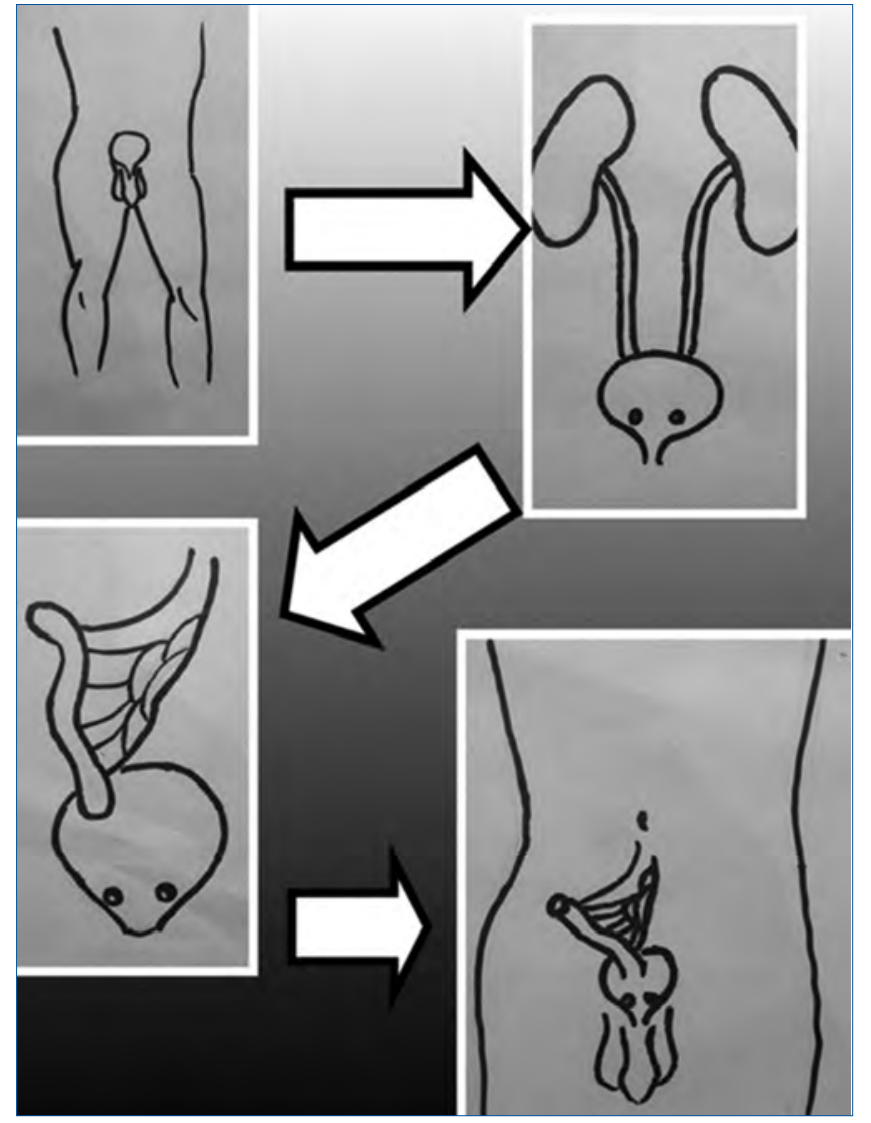

1. ÁBRA: A VESICOILEOCUTAN SZTÓMAKÉPZÉS SÉMÁS ÁBRÁJA

\section{Betegek és módszer}

Klinikánkon 2006 és 2015 között négy esetben képeztünk vesicoileocutan sztómát húgycsőszúkület és inkontinencia miatt. Első esetben traumás medencetörés, a második esetben méhnyakrák miatti irradiáció, a harmadik esetben többszöri TURP-mútét, a negyedik betegnél radikális prostatectomia volt a húgycső teljes elzáródásának az oka. Mindegyik betegnél a szükületet először urethrotomiákkal próbáltuk oldani, amelyek középtávon is sikertelenek voltak, újból és újból beszúkült, míg végül elzáródott a húgycső. Mind a négy válogatott esetben lehetőség volt az egészséges húgyhólyag megtartására és a hasfal épsége miatt vizeletes sztóma kialakítására (1. táblázat).

\section{Mütéttechnika}

A szabályos előkészítés után a beteg lábát szétnyitva, hátára fektettük majd intratrachealis narkózis történt. Medián laparotomiás metszést követően a belek összenövéseit oldottuk. Felkerestük a terminális ileumot, amelyből 10-15 cm-t izoláltunk. A bél folytonosságát gépi varratokkal helyreállítottuk majd bezártuk a mesenterium ablakot csomós öltésekkel. Az izolált bélszakaszt a hólyag jobb oldalához csatlakoztattuk úgy, hogy a hólyag falából egy $2 \mathrm{~cm}$ átmérójú kört vágtunk ki. A tág anasztomózis miatt szúkület ritkán fordulhat elő. A bél másik, aborális végéből vizeletes sztómát készítünk a spina iliaca anterior superiort és a köldököt összekötő képzeletbeli vonalban (1. ábra). A bél végét kifordítottuk, hogy kiemelkedjen, mert így a sztómazsák korongja könnyebben felhelyezhető. Fontos odafigyelni, hogy a közbeiktatott bélszakasznak egyenesnek kell lennie és ideális hosszúságúnak, különben a vizelet nem fog tudni akadálytalanul kiürülni, illetve esetleg szükséges katéterezést a bél kanyargóssága nagyon megnehezíti.

A mútéti idő rövidebb, mint egy Bricker-hólyag képzésnél, kisebb operatív és posztoperatív megterhelést jelent a beteg számára, a gyógyulás is rövidebb. A hólyag megtartásával elkerülhető az uréterek és a bél közötti anasztomózis szúkülete, így a felső húgyutak épsége jobban megőrizhető.

Saját esetekben mindig inkontinens sztómát alakítottunk ki, mert a betegek, bár részletesen tájékoztattuk őket, az önkatéterezéstől féltek, nem vállalták (2. ábra).

\section{Eredmények}

Korai posztoperatív szövődmény eseteinkben nem fordult eló. Az egyéves kontrollnál a felső húgyutak épek maradtak, egy esetben a sztóma beszúkült, amit lézerrel felmetszettünk. Ugyanennél a betegnél a húgycső fisztulát képzett a gát felé, ezt Pfannenstiel-metszésből nyitottan zártunk. Egy másik esetben parasztómális sérv alakult ki. Laparotomia után a sérvtömlőből a beleket eltávolítottuk és a sztómát áthelyeztük, a köldök helyén kiszájaztattuk. Betegeink az elért eredményekkel elégedettek, a sztóma gondozását könnyedén elsajátították.

\section{Megbeszélés}

Inkontinens felnőttkori vesicoileocutan sztómáról nagyon kevés külföldi irodalmi feljegyzést találtunk (2). A szakirodalom főleg a gyermekkorban előforduló kontinens vesicocutan sztómát említi, amelyet általában appendixból készítenek és leggyakoribb oka a myelomeningocele és a hátsó urethrabillentyű (3). Magyar szakirodalmi hivatkozást a felnőttkori inkontinens vesicoileocutan sztómával kapcsolatban nem találtunk.

1. TÁBlÁZAT: VesicolleoCutAN SZTÓMAKÉPZÉSEN ÁTESETT BETEGEK ADATAI

\begin{tabular}{|c|c|c|c|}
\hline Születési év & Nem & Ok & Szövődmény \\
\hline 1947 & Férfi & $\begin{array}{c}\text { Radikális } \\
\text { prostatectomia }\end{array}$ & Nem volt \\
\hline 1950 & Férfi & TURP & $\begin{array}{l}\text { Perinealis fisztula, } \\
\text { sztómaszúkület }\end{array}$ \\
\hline 1952 & Nő & $\begin{array}{l}\text { Irradiáció } \\
\text { (nőgyógy. tumor) }\end{array}$ & Nem volt \\
\hline 1977 & Nő & $\begin{array}{l}\text { Kismedencei } \\
\text { trauma }\end{array}$ & $\begin{array}{l}\text { Parastomalis } \\
\text { hernia }\end{array}$ \\
\hline
\end{tabular}




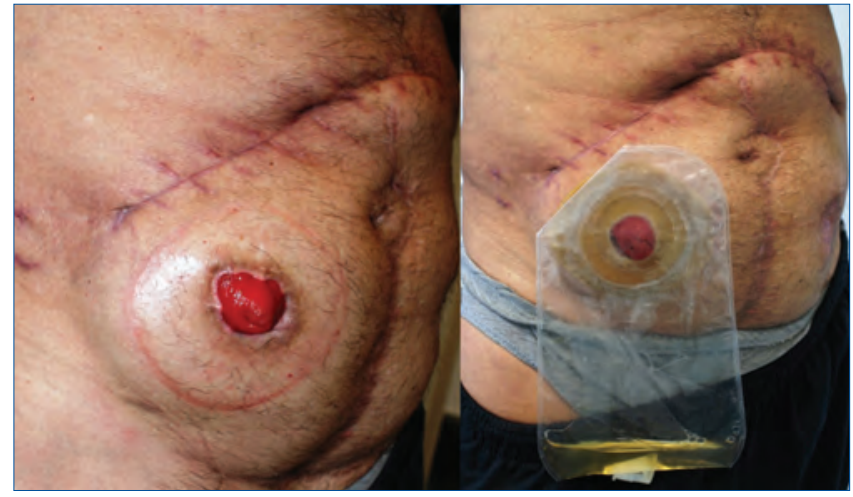

2. ÁBRA: A KÉSZ VIZELETES SZTÓMA ÉS A SZTÓMAZSÁK FELHELYEZVE
Ezek alapján is látszik, hogy ezt a módszert ritkán alkalmazzák. Leggyakrabban definitív epicystostomát képeznek, amely a rendszeres csere - a betegeknek fájdalmas - és gyakori fertőződés, kőképződés miatt nem megfelelő megoldás.

\section{Következtetés}

Egyes válogatott esetekben - ahol a hólyag eltávolítása nem szükséges - a vizeletelvezetés így megvalósítható. A húgyhólyag megtartásával, az eredeti uréterszájadékok változatlanul múködnek, így elkerülhető az anasztomózis-képzés a vékonybél és az uréterek között, a felső húgyutak épsége megőrizhető. A betegnek a normális életvitelét a sztóma alig zavarja, a fenyegető teljes vizeletelakadás pedig többet nem fordulhat elő.

\section{Irodalom}

1. Zhou SK, et al. Etiology and Management of Male latrogenic Urethral Stricture: Retrospective Analysis of 172 Cases in a Single Medical Center. Urol Int 2016 Jun 14. DOI: http://dx.doi.org/10.1159/ 000444592

2. DA Rivas, et al. Cutaneous ileocystostomy (a bladder chimney) for the treatment of severe neurogenic vesical dysfunction. Paraplegia 1995; 33: 530-535. DOI: http://dx.doi.org/10.1038/sc. 1995.114

3. Ching $\mathrm{CB}$, et al. Outcomes of incontinent ileovesicostomy in the pediatric patient. J Urol 2014 Feb; 191(2): 445-50. DOI: http:// dx.doi.org/10.1016/j.juro.2013.08.008 